\title{
Estimating Potential Evapotranspiration in Maranhão State Using Artificial Neural Networks
}

\author{
Klara Cunha de Meneses ${ }^{1}$ (D), Lucas Eduardo De Oliveira Aparecido ${ }^{2}$ (D), \\ Kamila Cunha de Meneses ${ }^{3}$ (D), Maryzélia Furtado de Farias ${ }^{1}$ \\ ${ }^{1}$ Universidade Federal do Maranhão, Chapadinha, MA, Brasil. \\ ${ }^{2}$ Instituto Federal do Mato Grosso do Sul, Navirai, MS, Brasil. \\ ${ }^{3}$ Departamento de Engenharia e Ciências Exatas, Universidade Estadual de São Paulo, \\ Jaboticabal, SP, Brasil.
}

Received: 10 March 2020 - Accepted: 31 March 2020

\begin{abstract}
The use of technology and planning in agricultural production is essential in Northeastern Brazil, which is the region of the country that most suffers from water shortage. For the best irrigation management, it is necessary to know the potential evapotranspiration rate for water control in order to increase productivity. There are several direct and indirect methods for estimating evapotranspiration, but the standard method recommended by the United Nations Agriculture Organization (FAO) is the Penman-Monteith (PETpm) method because it has higher accuracy than other methods. However, it is a difficult method to be used due to the need for a large number of meteorological elements. In this context, the objective of this study was to estimate potential evapotranspiration by the Penman-Monteith method in the micro-region of Baixo Parnaíba in Maranhão state using artificial neural networks. Agro-meteorological data were collected daily over 34 years, from 1984 to 2017, and these data were obtained from the NASA/POWER website. Subsequently, liquid radiation and potential evapotranspiration were calculated by the Penman-Monteith standard method (1998). To predict potential daily evapotranspiration, the Multi-Layer Perceptron (MLP) was chosen, which is a traditional Artificial Neural Network. The period that presented a higher evapotranspiration index was the same one that showed precipitation with a lower volume and higher temperatures. The artificial neural network model that best adapted to estimate PETpm was MLP 2-5-1. It is concluded that artificial neural networks estimate with accuracy and precision the Penman-Monteith daily potential evapotranspiration of the Lower Parnaiba in Maranhão, and potential evapotranspiration can be estimated by the Penman-Monteith method using neural networks with inputs of air temperatures.
\end{abstract}

Keywords: climatic elements, artificial intelligence, modeling.

\section{Estimativa da evapotranspiração potencial no estado do Maranhão utilizando redes neurais artificiais}

\begin{abstract}
Resumo
O uso de tecnologia e planejamento na produção agrícola é essencial, principalmente, no Nordeste do Brasil, que é a região do país que mais sofre com a escassez hídrica. Para o melhor manejo da irrigação torna-se necessário o conhecimento da taxa de evapotranspiração potencial para o controle e economia de água aumentando a produtividade. Existe vários métodos diretos e indiretos para a estimativa de evapotranspiração, mas o método padrão recomendado pela Organização das Nações Unidas para Agricultura (FAO) é o método Penman-Monteith (ETPPM) por ter uma alta precisão em relação aos demais métodos. Entretanto, é um método difícil de ser utilizado devido à necessidade de uma grande quantidade de elementos meteorológicos. Diante desse contexto, objetivou-se estimar a ETPPM na microrregião do Baixo Parnaíba maranhense utilizando redes neurais artificiais, visando facilitar a utilização deste método tão acurado. Os dados agrometeorológicos coletados foram de 34 anos, a partir do ano de 1984 até o ano de 2017 em escala diária, obtidos do site NASA/POWER. Posteriormente, foram calculadas a radiação liquida e a evapotranspiração potencial pelo método
\end{abstract}

Autor de correspondência: Lucas Eduardo De Oliveira Aparecido, lucas.aparecido@ifms.edu.br. 
padrão Penman-Moteith (1998). Para prever a evapotranspiração potencial diária foi escolhida a Perceptron Multi-Layer (MLP), que é uma Rede Neural Artificial tradicional. O período que apresentou um maior índice de evapotranspiração foi o mesmo que apontou precipitações com um menor volume e temperaturas elevadas. O modelo de rede neural artificial que melhor se adequou para estimativa da ETPPM foi a MLP 2-5-1. Com isto, conclui-se que as redes neurais artificiais podem ser utilizadas para a estimativa da ETPPM diária do Baixo Parnaíba maranhense. É possível estimar a evapotranspiração potencial por Penman-Monteith usando redes neurais com inputs de temperaturas do ar.

Palavras-chave: elementos climáticos, inteligência artigicial, modelagem.

\section{Introduction}

Water shortage in the Northeast region of Brazil is a great problem compared to other regions of the country, and for the expansion of the agricultural sector and the rational use of water it is essential to apply technology and planning for the most efficient irrigation to occur in this region (Andrade Junior et al., 2018; Freitas et al., 2018). Furthermore, increased temperature and reduced precipitation causes increased water demand for crops (Gava et al., 2015) and damages agricultural production.

Establishing the water requirements of a crop in its different stages of development is of fundamental importance for irrigation management to acheive good productivity and rational water use (Costa et al., 2018). For this to occur it is necessary to know the evapotranspiration rate of the plant in order to irrigate with the correct amount, with the goal of increasing production without waste of water.

Evapotranspiration is the process in which water from the earth's surface evaporates into the atmosphere together with the transpiration of plants, being an important part of the hydrological cycle (Alves et al., 2017). The process of evapotranspiration occurs not only from surface water, but also involves the loss of soil water and moist vegetation in the form of water vapor and the loss of water from animals (perspiration) and plants through transpiration. Thus, the study of daily evapotranspiration rates is very useful for establishing water requirements in agriculture (Martins and Rosa, 2019).

To estimate the amount of water required by a plant it is necessary to calculate the potential evapotranspiration, and this can be done by several empirical methods (Andrade Junior et al., 2018). The Food and Agriculture Organization (FAO) recommends Penman-Monteith as a standard method, since it is considered a more accurate model (Allen et al., 1998). What makes it difficult to use is the need for various climatic elements, such as relative humidity, solar radiation, air temperature, and wind speed. This method requires a larger number of weather variables and these elements are often not available due to the small number of weather stations available in many regions, and when these are present they may contain insufficient data (Alves et al., 2017). In the literature there are other empirical methods with fewer requirements for climatic variables (Silva et al., 2018, Caporusso and Rolim, 2015), such as Hargreaves-Samani, Solar Radiation, Blaney-
Criddle and Priestley-Taylor (Allen et al., 1998), but these methods oftentimes have large deviations. One way to accurately estimate PETpm is by using artificial intelligence, such as through artificial neural networks (ANN).

In the last decade, intelligent computational models have been developed as alternative methods to estimate potential evapotranspiration (Yassin et al., 2016), and ANN is one of the techniques that can be used. ANN are mathematical models that simulate the neural structures of the human brain and build computational intelligence through learning and generalization (Di Domenico et al., 2017). This method has a nonlinear structure that captures the most complex characteristics of the data, which is difficult to achieve using other traditional statistical techniques (Conti et al., 2016; Nunes, 2018).

In recent years, ANN applications have been used in the estimation of PET and the results suggest that artificial neural networks are more accurate than conventional methods (Dai et al., 2009; Abdullahi et al., 2017). However, the use of empirical models of potential evapotranspiration that use only air temperature as input data is relevant in regions with a shortage of climatic data, and in the commercial market there are devices that can measure this variable with low cost, such as thermo-hygrometers.

Water shortage and growing demand for food supply increase the importance of developing improved methods for estimating potential evapotranspiration (Patil and Deka, 2016). In this context, the objective of the study was to estimate potential evapotranspiration by the PenmanMonteith method in the micro-region of Baixo Parnaíba in the Maranhão state using artificial neural networks.

\section{Material and Methods}

The study area was in the Baixo Parnaíba microregion in the state of Maranhão, composed of 16 localities (Fig. 1 and Table 1). This region has high potential for farming due to great availability of soils and water resources.

The historical data series includes minimum, maximum, and mean air temperature $\left({ }^{\circ} \mathrm{C}\right)$, global radiation $\left(\mathrm{MJ} \mathrm{m}^{2}\right.$ day), precipitation ( $\left.\mathrm{mm}\right)$, wind speed $\left(\mathrm{m} \mathrm{s}^{-1}\right)$, and relative humidity (\%) from 34 years (1984 to 2017) of daily measurements. Climatic data were collected from the NASA/POWER website (Stackhouse et al., 2017). This data platform has a spatial resolution of $0.5^{\circ}$ latitude-longitude. 

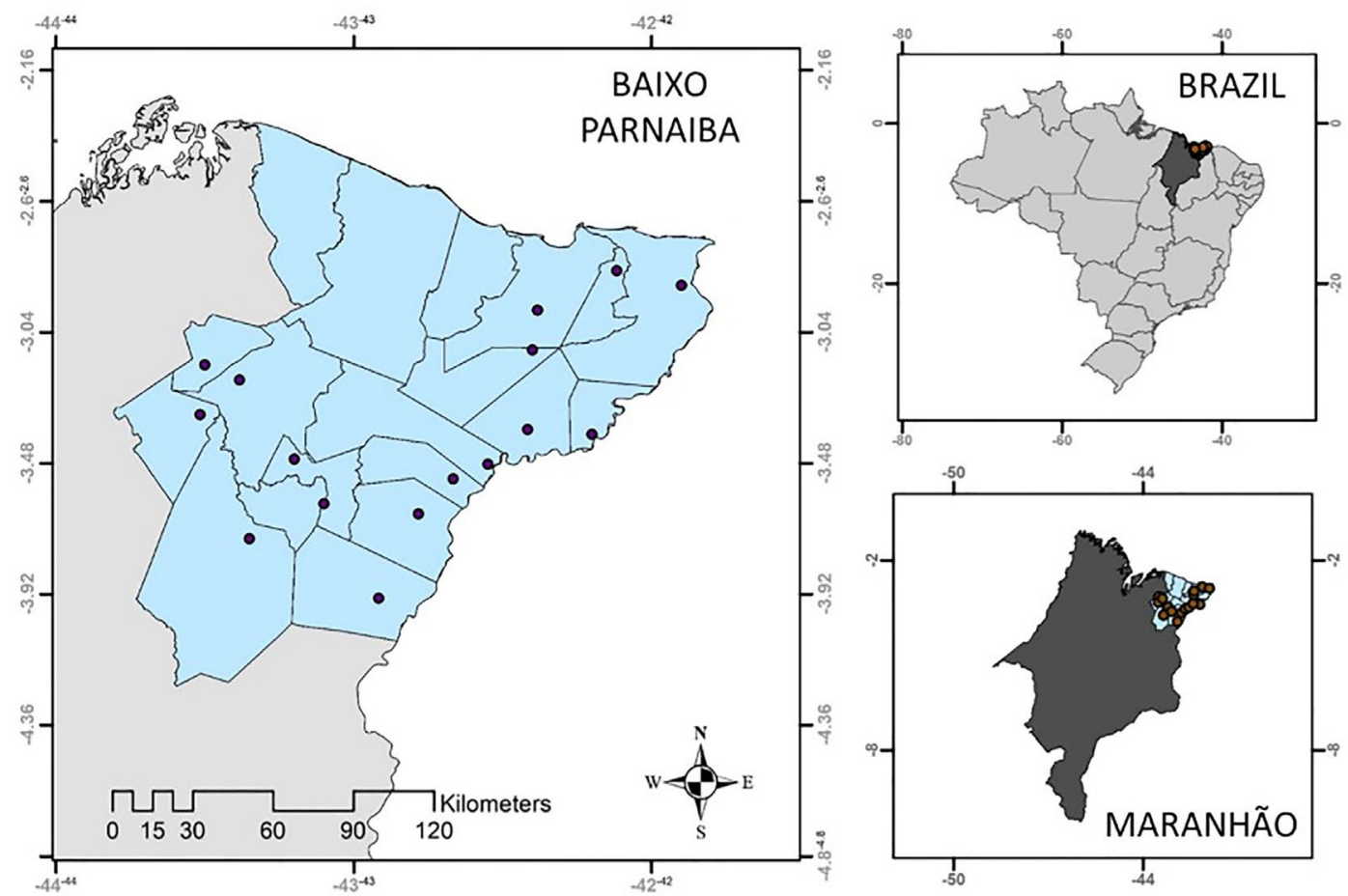

Figure 1 - Location of the Baixo Parnaíba microregion in Maranhão state, Brazil.

Table 1 - Localities of the Baixo Parnaíba microregion with geographical coordinates and altitude.

\begin{tabular}{lllc}
\hline \multicolumn{1}{c}{ Localities (Maranhão) } & Latitude $\left(^{\circ}\right)$ & Longitude $\left(^{\circ}\right)$ & Altitude (m) \\
\hline Água Doce do Maranhão & $2^{\circ} 50^{\prime} \mathrm{S}$ & $42^{\circ} 7^{\prime} \mathrm{W}$ & 16 \\
Anapurus & $3^{\circ} 28 \mathrm{~S}$ & $43^{\circ} 12^{\prime} \mathrm{W}$ & 91 \\
Araioses & $2^{\circ} 53^{\prime} \mathrm{S}$ & $41^{\circ} 54^{\prime} \mathrm{W}$ & 16 \\
Belágua & $3^{\circ} 9^{\prime} \mathrm{S}$ & $43^{\circ} 30^{\prime} \mathrm{W}$ & 72 \\
Brejo & $3^{\circ} 39^{\prime} \mathrm{S}$ & $42^{\circ} 47^{\prime} \mathrm{W}$ & 61 \\
Chapadinha & $3^{\circ} 44^{\prime} \mathrm{S}$ & $43^{\circ} 21^{\prime} \mathrm{W}$ & 104 \\
Magalhães de Almeida & $3^{\circ} 23^{\prime} \mathrm{S}$ & $42^{\circ} 12^{\prime} \mathrm{W}$ & 38 \\
Mata Roma & $3^{\circ} 37^{\prime} \mathrm{S}$ & $43^{\circ} 6^{\prime} \mathrm{W}$ & 77 \\
Milagres do Maranhão & $3^{\circ} 32^{\prime} \mathrm{S}$ & $42^{\circ} 40^{\prime} \mathrm{W}$ & 100 \\
Santa Quitéria do Maranh & $3^{\circ} 29^{\prime} \mathrm{S}$ & $42^{\circ} 33^{\prime} \mathrm{W}$ & 30 \\
Santana do Maranhão & $3^{\circ} 6^{\prime} \mathrm{S}$ & $42^{\circ} 24^{\prime} \mathrm{W}$ & 37 \\
São Benedito do Rio Preto & $3^{\circ} 19^{\prime} \mathrm{S}$ & $43^{\circ} 31^{\prime} \mathrm{W}$ & 60 \\
São Bernardo do Maranhão & $3^{\circ} 22^{\prime} \mathrm{S}$ & $42^{\circ} 25^{\prime} \mathrm{W}$ & 54 \\
Tutóia & $2^{\circ} 58^{\prime} \mathrm{S}$ & $42^{\circ} 23^{\prime} \mathrm{W}$ & 48 \\
Urbano Santos & $3^{\circ} 12^{\prime} \mathrm{S}$ & $43^{\circ} 23^{\prime} \mathrm{W}$ & 68 \\
\hline
\end{tabular}

We calculated the potential evapotranspiration using the Penman-Monteith (Allen et al., 1998) method, according to (Eqs. (1-8)).

$$
P E T=\left(\frac{0.48 \times \Delta \times(R n-G)+\left(\frac{900}{T+273}\right) \times U 2(e s-e)}{\Delta+\gamma \times(1+0.34 \times U 2)}\right)
$$

$$
\begin{gathered}
\Delta=\frac{4098 \times e s}{(T+273)^{2}} \\
e s=0.6108 \times e^{\frac{17.27 \times T}{237 .+T}} \\
e a=\frac{R H \times e s}{100} \\
R n=B O C-B O L \\
B O C=(1-\alpha) \times \mathrm{Rs} \\
-\left[4.903 \times 10^{-9}\left[\frac{T_{\max }^{4}+T_{\min }{ }^{4}}{2}\right](0.34-0.14 \sqrt{e a})\right. \\
\left.\times\left(1.35 \frac{R s}{R s o}-0.35\right)\right] \\
R s o=\left(0.75+2 \times 10^{-5} \times 11\right) \times R a
\end{gathered}
$$

where PET - Potential Evapotranspiration, in $\mathrm{mm} \mathrm{day}^{-1}$; $R n$ - net radiation, in $\mathrm{MJ} \mathrm{m}^{-2} \mathrm{day}^{-1} ; G$ - soil heat flux, in $\mathrm{MJ} \mathrm{m}{ }^{-2}$ day $^{-1} ; T$ - mean daily air temperature, in ${ }^{\circ} \mathrm{C} ; \gamma$ Psychometric constant $\left(0.063 \mathrm{kPa}{ }^{\circ} \mathrm{C}^{-1}\right) ; \Delta$ - is the humidity pressure curve decline at the air temperature, in $\mathrm{kPa}{ }^{\circ} \mathrm{C}^{-1} ; U 2$ - Average daily wind speed at $2 \mathrm{~m}$, in $\mathrm{m} \mathrm{s}^{-1}$; 
$e a$ - humidity partial pressure, in $\mathrm{kPa}$; es - humidity saturation pressure, daily average, in $\mathrm{kPa}$; Tmax - Maximum temperature $\left({ }^{\circ} \mathrm{C}\right)$; Tmin - Minimum temperature $\left({ }^{\circ} \mathrm{C}\right) ; R H$ - relative humidity $(\%) ; B O C$ is the shortwave radiation balance ( $\mathrm{MJ} \mathrm{m}^{-2} \mathrm{day}^{-1}$ ) and $B O L$ is the longwave radiation balance $\left(\mathrm{MJ} \mathrm{m}^{-2} \mathrm{day}^{-1}\right)$; Rs is the incident solar radiation $\left(\mathrm{MJ} \mathrm{m}{ }^{-2} \mathrm{day}^{-1}\right) ; \alpha$ is the coefficient of reflection of vegetation; $R s o$ is the incident solar radiation in the absence of clouds ( $\mathrm{MJ} \mathrm{m}{ }^{-2} \mathrm{dia}^{-1}$ ), and $R a=$ solar radiation at the top of the atmosphere $\left(\mathrm{MJm}^{-2} \mathrm{dia}^{-1}\right)$.

Daily minimum, mean, and maximum air temperature and potential evapotranspiration data were randomly divided into two sets of data values, one for network training $(139,000)$ and the other to evaluate the validation of the trained network $(59,613)$, with a ratio of about $70 \%$ of the data for training and $30 \%$ for validation, respectively.

The definition of the architecture of networks is the number of neurons per layer and number of layers, and is optimized by the Intelligent Problem Solver tool (IPS) of the Statistica 7 software (Statsoft, 2007). The training itself and the verification of the network and validation of the process were performed by IPS.

To predict daily PETpm, the Perceptron Multi-Layer (MLP) was chosen, which is a traditional Artificial Neural Network that has three stages: input, processing, and output (Fig. 2). Numerous topologies and variations were tested between neurons in the intermediate and outer layers until the most accurate ones were obtained. The ANN input data were the maximum, mean, and minimum air temperatures $\left({ }^{\circ} \mathrm{C}\right)$.

A layered MLP, with $\mathrm{H}$ hidden neurons, and an output neuron can be expressed by Eq. (9) in mathematical language.

$$
Y=S_{K}\left(\sum_{h=1}^{H} O_{h} W_{h} W_{o}\right)
$$

where $\mathrm{Y}$ is the RNA output;

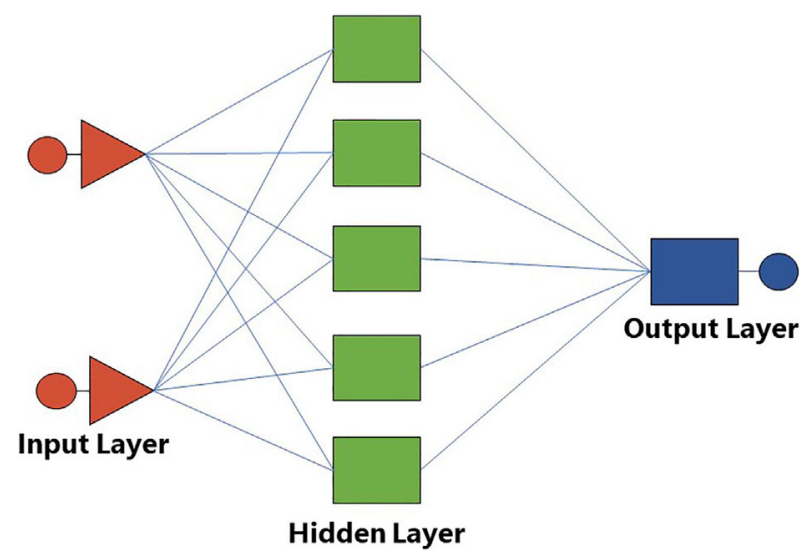

Figure 2 - Representation of a simplified Multilayer Perception (MLP) neural network.
Oh is the output value of the Hth occult neuron, with Oh given by (Eq. (10)):

$$
O h=S k\left(\sum_{h=1}^{H} X W_{n h} W_{o h}\right)
$$

where $\mathrm{Xn}$ is the RNA output; WNh and Wh are the synaptic weights between hidden neurons and RNA outputs and inputs, respectively, Xo is 1 , and Wo and Woh are initial values of RNA training algorithms.

The activation function is the logistic sigmoid given by (Eq. (11)):

$$
S k(x)=11+e-x
$$

where $\mathrm{x}$ is the sample mean that forms the training set.

The following statistical indices were used to assess the performance of the RNA: 1) Pearson correlation (r); 2) Coefficient of determination (R2); 3) Wilmott's agreement (d); 4) Camargo and Sentelhas Confidence Index (C) (1997); 5) Random error (Ea); 6) Systematic error (Es); 7) Maximum absolute error (EAmax); 8) Middle square error (MSE); 9) Middle root square error (RMSE); 10) Mean absolute error (MAE); 11) Mean absolute percentage error (MAPE) (Eqs. (12-22)).

$$
r=\frac{\sum_{i=1}^{n}\left(Y_{O B S i}-\bar{Y}_{O B S}\right) \times\left(Y_{E S T i}-\bar{Y}_{E S T}\right)}{\sqrt{\sum_{i=1}^{n}\left(Y_{O B S i}-\bar{Y}_{O B S}\right)^{2}} \times \sqrt{\sum_{i=1}^{n}\left(Y_{E S T i}-\bar{Y}_{E S T}\right)^{2}}}
$$

$$
\begin{gathered}
R^{2} \text { adjusted }=\left[1-\frac{\left(1-R^{2}\right) x(n-1)}{N-k-1}\right] \\
d=1-\frac{\sum_{i=1}^{N}\left(Y_{O B S i}-Y_{E S T i}\right)^{2}}{\sum_{i=1}^{N}\left(\left|Y_{E S T i}-\bar{Y}\right|+\left|Y_{O B S i}-\bar{Y}\right|\right)}
\end{gathered}
$$

$$
c=r \times d
$$

$$
\begin{gathered}
E a=\sqrt{\frac{\sum_{i=r}^{N}\left(Y_{E S T i}-Y\right)^{2}}{N}} \\
E S=\sqrt{\frac{\sum_{i=1}^{N}\left(Y_{O B S i}-Y\right)^{2}}{N}} \\
M E=\max \left(\left|Y_{O B S i}-Y_{E S T i}\right|\right)_{i=1}^{n}
\end{gathered}
$$




$$
\begin{gathered}
M S E=\frac{\sum_{i=1}^{N}\left(Y_{O B S i}-Y_{E S T i}\right)^{2}}{N} \\
R M S E=\sqrt{\frac{\sum_{i=r}^{N}\left(Y_{O B S i}-Y_{E S T i}\right)}{N}} \\
M A E=\frac{\sum_{i=r}^{N}\left|Y_{O B S i}-Y_{E S T i}\right|}{N} \\
\operatorname{MAPE}(\%)=\frac{\sum_{i=r}^{n}\left(\left|\frac{Y_{E S T i}-Y_{O B S i}}{Y_{O B S i}}\right| x 100\right)}{N}
\end{gathered}
$$

where Yest: Variable estimated by RNA; Yobsi: Variable observed; N: Number of data; k: Number of independent variables in the regression.

The criterion adopted to interpret performance by the Camargo and Sentelhas confidence index (1997) can be observed in Table 2 .

\section{Results and Discussion}

The mean values of maximum, minimum and mean air temperatures in the 16 localities in the period 19842017 were $32{ }^{\circ} \mathrm{C}, 24{ }^{\circ} \mathrm{C}$, and $28^{\circ} \mathrm{C}$ (Fig. 3) respectively. The mean maximum temperature of the region occassionally reached almost $40{ }^{\circ} \mathrm{C}$. In the spatial evaluation, the lowest minimum air temperatures occurred in the Southern region, with values ranging from $22.69{ }^{\circ} \mathrm{C}$ to $22.99^{\circ} \mathrm{C}$. However, the highest maximum air temperature was predominant in Araioses, $30.45^{\circ} \mathrm{C}$ (Fig. 4).

The highest rainfall occurred in the period from March to April and the lowest in the period from August to November (Fig. 5). In March, the accumulated monthly rainfall was $312 \mathrm{~mm}$, while the month of September had $12 \mathrm{~mm}$. The months that had a higher precipitation rate are considered the rainy season and months with lower rainfall volumes are considered the dry season in the microregion. Passos et al. (2016), in a study of water balance and climatic classification for the Chapadinha-MA region, which is one of the cities of the micro-region observed in

Table 2 - Confidence Index (C) established by Camargo and Sentelhas (1997).

\begin{tabular}{lc}
\hline Value $(\mathrm{C})$ & Performance \\
\hline$>0.85$ & Excellent \\
0.76 to 0.85 & Very good \\
0.66 to 0.75 & Good \\
0.61 to 0.65 & Satisfactory \\
0.51 to 0.60 & Poor \\
0.41 to 0.50 & Bad \\
$<0.40$ & Very bad \\
\hline
\end{tabular}

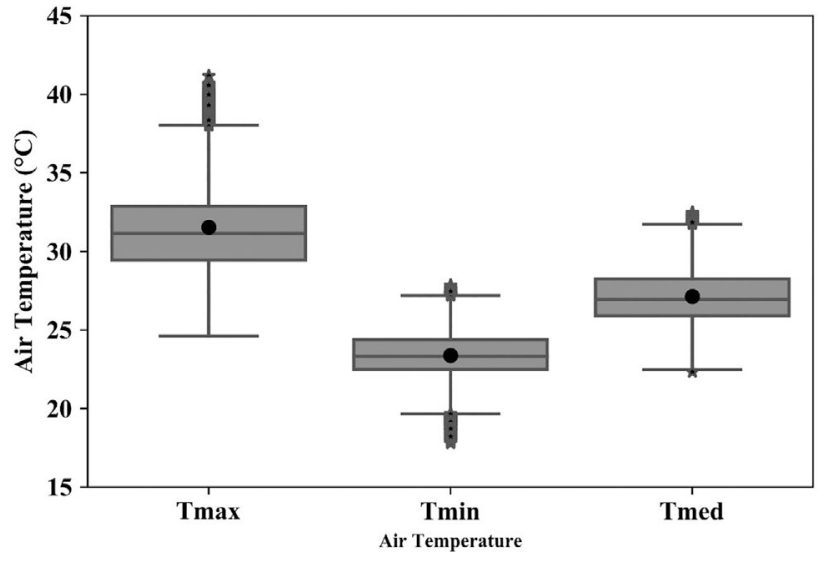

Figure 3 - Boxplot with the maximum, minimum and mean daily air temperature data of the Baixo Parnaíba micro-region in the period 19842017. Tmax is maximum air temperature; Tmin is minimum air temperature and Tmed is mean air temperature.

the current study, described two well-defined seasons, the rainy season from January to May, with $84 \%$ of total annual precipitation in these months, and the dry season from June to December which had $16 \%$ of total rainfall.

The increase in air temperature in the Baixo Parnaíba region occurred in August. Between February and July, the mean monthly air temperature was $26{ }^{\circ} \mathrm{C}$. In the period from April to October, there was an increase in PET in the micro-region of Baixo Parnaíba (Fig. 6), and the lowest PET of the region occurred in April. October had the highest potential evapotranspiration value of the region, and the period from August to October presented a high PET index which coincided with a lower precipitation volume. Freitas et al. (2018) observed that the months that presented higher precipitation also had the lowest rate of PET, and this was due to the occurrence of rain events wherein air masses create a barrier that hinders the incidence of solar radiation, and as a result evapotranspiration rates are reduced.

The arrangement of the MLP artificial neural network that best adapted to estimate PETpm was MLP 2-51 , that is, with two input variables, five neurons in the hidden layer and one output. Among the models presented, MLP 2-5-1 was the one that was most able to express in a simplified way all the variation of PETpm. This is because this multi-layered RNA (MLP) method has a more complex (non-linearly separable) solution than methods with only one layer that have the ability to solve only linearlyseparable problems. Tabari and Talaee (2013) indicated that the main difficulty in applying the PM equation is due to the requirement for a wide variety of meteorological data that must be used as input for the calculation of PET. In addition, $P E T$ is non-linear, which would make it difficult to accurately affect changes in climatic parameters. Therefore, the use of MLP neural network techniques may have better performance, as these can solve separable nonlinear equations. 

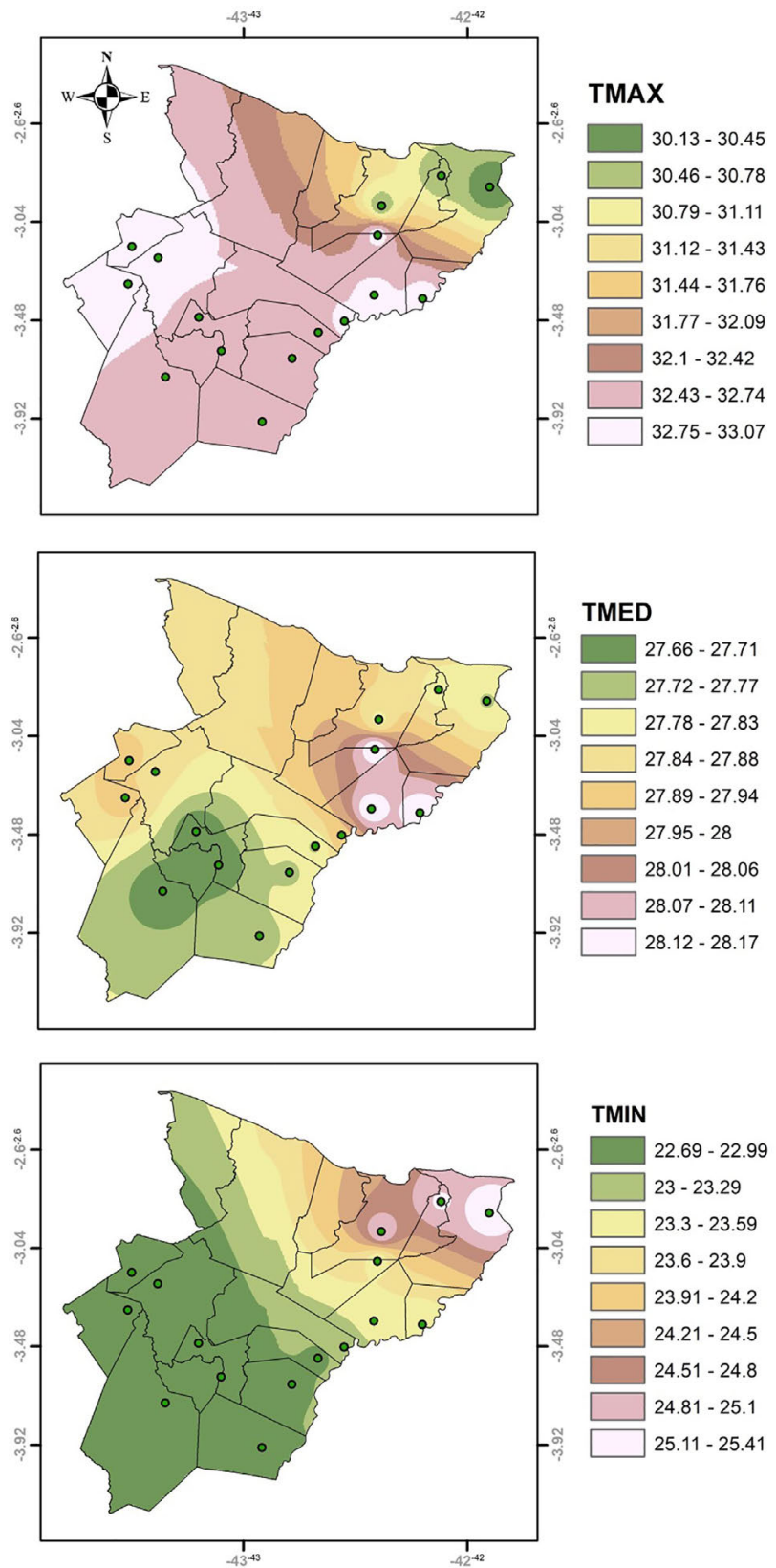

Figure 4 - Spatial variability of maximum, minimum and mean temperatures in the Baixo Parnaiba micro-region in the period 1984-2017. Tmax is maximum temperature; Tmin is minimum air temperature and Tmed is the mean air temperature.

In the sensitivity analysis of the input variables of the artificial neural network, the maximum and minimum air temperatures were the highest sensitivities variables in the estimate of PETpm, respectively (Table 3). The maximum air temperature was the one with higher sensitivity, while the minimum air temperature was next in the sensitivity analysis, and the mean temperature did not present sensitivity in the model, probably because it was correlated with these variables.

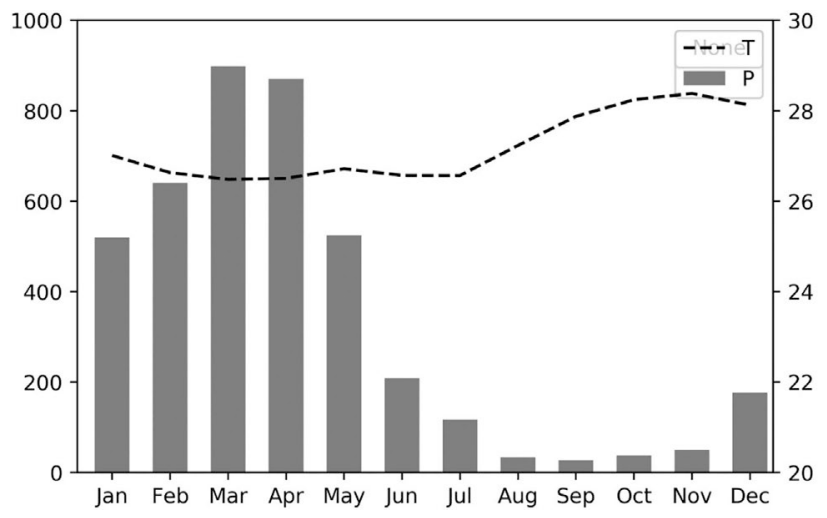

Figure 5 - Mean monthly precipitation and air temperature values of the Baixo Parnaíba micro-region in Maranhão state, Brazil.

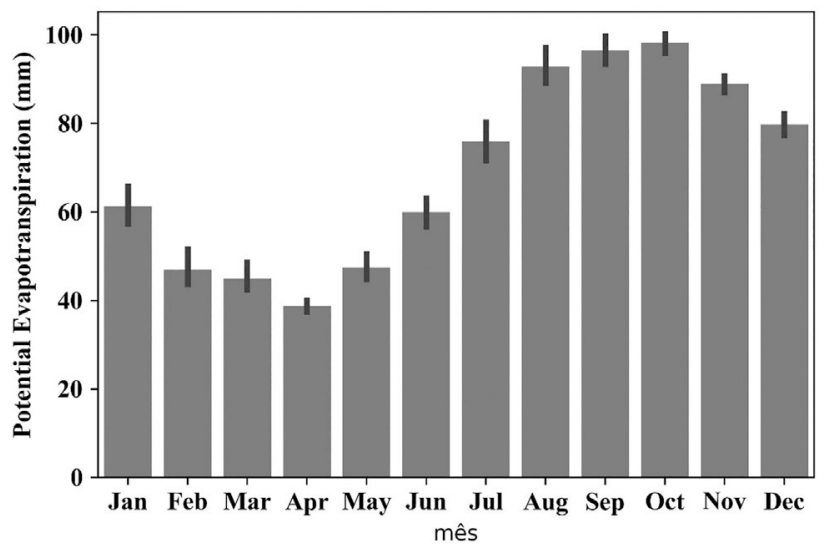

Figure 6 - Mean values of Penman - Monteith Potential evapotranspiration of the Baixo Parnaiba Maranhense Micro-region.

Table 3 - Sensitivity analysis for maximum, mean and minimium air temperatures.

\begin{tabular}{lccc}
\hline & TMax & TMin & TMed \\
\hline Ratio & 1.510989 & 1.148545 & - \\
Rating & $1^{\text {st }}$ & $2^{\text {nd }}$. & - \\
\hline
\end{tabular}

Statistical indices show that MLP can predict PETpm with accuracy. Both in training and the MLP test, MAPE was low and $\mathrm{R}^{2}$ was elevated (Table 4 ). For example, Pearson's correlation between the actual PETpm data and those estimated by the MLP was 0.955 and 0.959 for training and testing, respectively. The accuracy of the model was good because the value of the Root Mean Squared Error (RMSE) was only $0.331 \mathrm{~mm}$ and $0.327 \mathrm{~mm}$ for training and testing, respectively.

In the training of the network, it was able to explain $91.2 \%$ of the variation of the data of the actual PETpm using temperature data as input to the artificial neural network (Fig. 7). The average sensitivity of Penman-Monteith's daily PET estimated by the neural network was $0.8064 \mathrm{~mm} \mathrm{day}^{-1}$. The training sensitivity of $0.8064 \mathrm{~mm}$ 
Table 4 - Statistical indices used to evaluate the estimates of evapotranspiration by the artificial neural network.

\begin{tabular}{llcc}
\hline Acronym & Index & Training & Test \\
\hline $\mathrm{R}$ & Pearson Correlation & 0.955 & 0.959 \\
$\mathrm{R}^{2}$ & Determination & 0.912 & 0.920 \\
$\mathrm{D}$ & Agreement-Wilmott & 0.850 & 0.856 \\
$\mathrm{C}$ & Trust & 0.812 & 822 \\
$\mathrm{Ea}$ & Random Error & 0.108 & 0.105 \\
Es & Systematic Error & 0.313 & 0.310 \\
EAmax & Absolute maximum error & 2.425 & 2.271 \\
MSE & Mean Squared Error & 0.110 & 0.107 \\
RMSE & Root Mean Squared Error & 0.331 & 0.327 \\
MAE & Mean Absolute Error & 0.301 & 0.298 \\
MAPE* & Mean Absolute Percentage Error & 39.248 & 37.793 \\
\hline
\end{tabular}

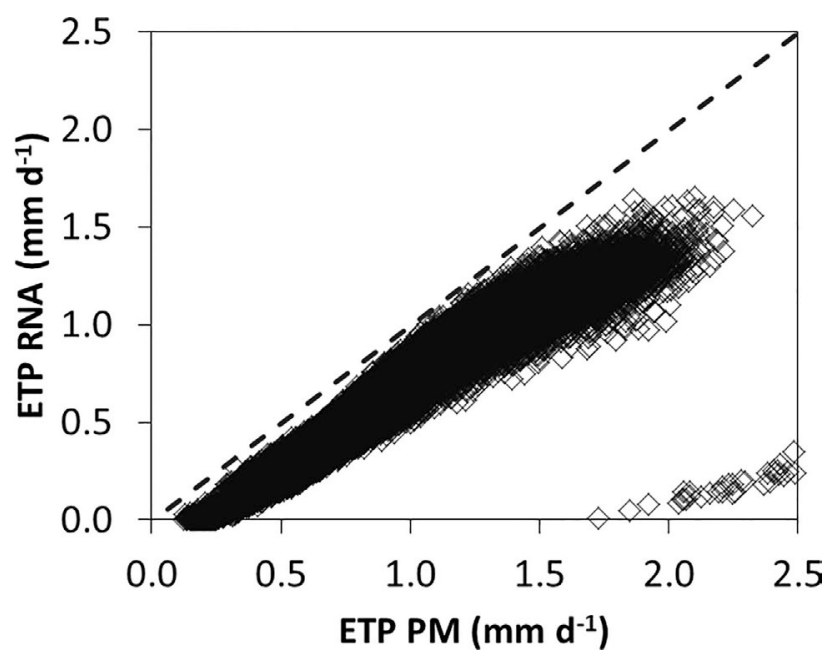

Figure 7 - Artificial neural network training to estimate potential Penman-Monteith Evapotranspiration.

day $^{-1}$ with the mean daily PET per neural network of $1 \mathrm{~mm}$ represents an increase of $0.8064 \mathrm{~mm}$ for every $1.40 \mathrm{~mm}$ of Penman-Monteith daily PET. Assuming the daily Penman-Monteith $P E T$ value of zero, the daily $P E T$ by neural networks will be $0.1242 \mathrm{~mm} \mathrm{day}^{-1}$. Training is one of the important stages of neural networks because adjustments are made to the weights so that the network can correctly organize the inputs and that the result corresponds with the desired value for each input vector.

In the validation of the PETpm data, the neural network was able to explain $92 \%$ of the total variation of the observed data. In general, there was an underestimation of MLP in the estimation of PETpm in all periods (Fig. 8). The results of the validation (generalization) of the model were similar to those of training. Validation separates the dataset into a training set that is used only to derive parameters that minimize the loss function and a validation set that is used only to evaluate model performance (Jahn,

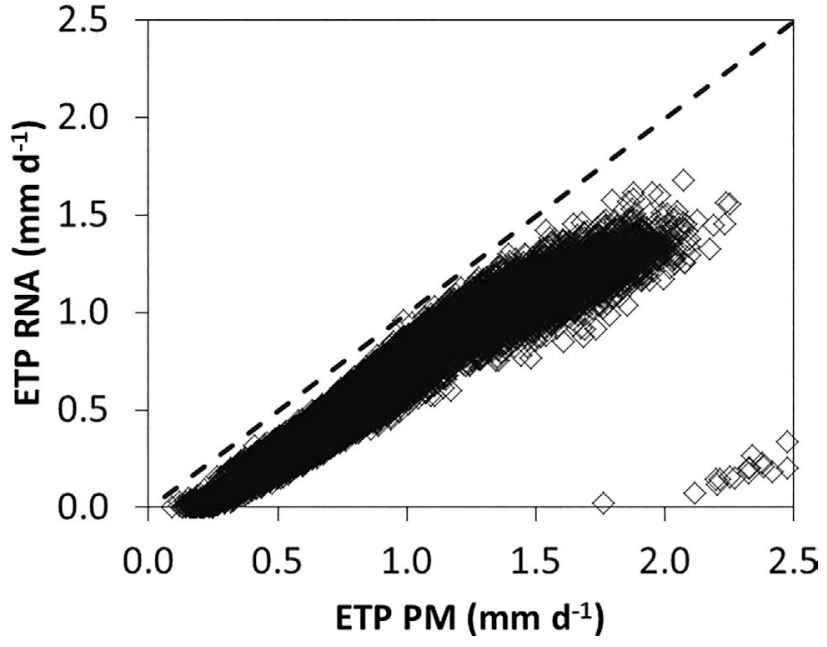

Figure 8 - Validation of the artificial neural network to estimate potential Penman-Monteith Evapotranspiration.

2018). After each interaction, the training session is interrupted to verify the error.

\section{Conclusions}

Artificial neural networks can accurately estimate the daily potential evapotranspiration by the PenmanMonteith method for the Baixo Parnaíba region in Maranhão. This study has shown that it is possible to estimate potential evapotranspiration by the Penman-Monteith method using neural networks with inputs of only air temperatures. Additionally, the artificial neural network underestimated potential evapotranspiration by the Penman-Monteith method, both in training and in testing.

\section{References}

Abdullahi, J.; Elkiran, G.; Nourani, V. Application of artificial neural network to predict reference evapotranspiration in Famagusta, North Cyprus. 11th International Scientific Conference on Production Engineering Development And Modernization of Production, p. 549-554, 2017.

Allen, R.G.; Pereira, L.S.; Raes, D.; Smith, M. Crop evapotranspiration: Guidelines for computing crop water requirements. In: Irrigation and Drainage Paper, n. 56. Rome: FAO, 1998.

Alves, W.B.; Rolim, G.S.; Aparecido, L.E.O. Reference evapotranspiration forecasting by artificial neural networks. Agricultural Engineering, v. 37, n. 6, p. 1116-1125, 2017.

Andrade Junior, A.S.; Silva, C.O.; Sousa, V.F.; Ribeiro, V.Q. Evaluation of methods for estimating reference evapotranspiration in the state of Piauí. Agrometeoros, v. 25, n. 1, p. 181-190, 2018.

Camargo, A.P.; Sentelhas, P.C. Evaluation of the performance of different methods of estimating potential evapotranspiration in the state of São Paulo. Revista Brasileira de Agrometeorologia, v. 5, n. 1, p. 89-97, 1997. 
Caporusso, N.B; Rolim, G.S. Reference evapotranspiration models using different time scales in the Jaboticabal region of São Paulo, Brazil. Minutes Scientiarum, v. 37, n. 1, p. 1-9, 2015.

Conti, G.; Wiggers, K. L.; Ribeiro, S.R.A. Representation in 3d meshes from soil texture data interpolated using artificial neural network: thick fescon-tip case study-pr. Geo UERJ, n. 28, p. 410-429, 2016.

Costa, J.A.; Rodrigues, G.P.; Silva, N.D.; Nephew, O.P.L.; Costa, L.D. Evaluation of methods for estimating reference evapotranspiration for Alagoas. Agrometeoros, v. 25, n. 1, p. 24-36, 2018.

Dai, X.; Shi, H.; Li, Y.; Ouyang, Z.; Huo, Z. Artificial neural network models for estimating regional reference evapotranspiration based on climate factors. Hydrological Processes: An International Journal, v. 23, n. 3, p. 442450, 2009.

DiDomenico, C.N.B.; Da Silva, F.J.N.; Ferreira, J.A.F. The use of artificial neural networks in the optimization of the process of convective drying of food and reduction of energy consumption. Revista Eletrônica Ágora, n. 24, p. 36-41, 2017.

Freitas, P.A.; Oliveira, L.M.M.; Sales Barbosa, R.F.; Montenegro, S.M.G. Evapotranspiration of daily reference by different models in the capibaribe river basin (PernambucoBrazil). Revista Brasileira de Ambiente, v. 4, n. 1, p. 2531, 2018.

Gava, R.; Frizzone, A.J; Snyder, R.L.; Jose, J.V.; Fraga Junior, E.F.; Perboni, A. A. hydroric stress at different stages of soybean crop. Revista Brasileira de Agricultura Irrigada, v. 9, n. 6, p. 349-359, 2015.

Jahn, M. Artificial neural network regression models: Predicting GDP growth. HWWI Research Paper, v. 1, n. 1, p. 301312, 2018.

Martins, A.P; Rosa, R. Estimate of real evapotranspiration from images of the MODIS/AQUA sensor and the SEBAL algo- rithm in the Paranaiba River basin - Brazil. Geography Notebook, v. 29, n. 57, p. 2318-2962, 2019.

Nunes, R.T.M. Predictive calculation of classification of enade notes using artificial neural networks. Journal of Applied Technology, v. 7, n. 2, p. 59-71, 2018.

Passos, M.L.V.; Zambrzycki, G.C.; Pereira, R.S. Water balance and climatic classification for a given region of Chapadinha-MA. Revista Brasileira de Agricultura Irrigada, v. 10, n. 4, p. 758-766, 2016.

Patil, A.P.; Deka, P.C. An extreme learning machine approach for modeling evapotranspiration using extrinsic inputs. Computers and Electronics in Agriculture, v. 121, p. 385-392, 2016.

Silva, J.P.M.; Cabacinha, C.D.; Assis, A.L.; Monteiro, T.C.; Junior, C.A.A.; Maia, R.D. D. Artificial neural networks to estimate the basic density of cerrado woods. Brazilian Forest Survey, v. 38, p. 12-24, 2018.

Stackhouse Jr., P.W.; Chandler, W.S.; Zhang, T.; Westberg, D.; Barnett, A.J.; Hoell, J.M.M. Surface Meteorology and Solar Energy (SSE) Release 6.0 Methodology. Version 3.2.0. https://eosweb.larc.nasa.gov/sse/documents/SSE6 Methodology.pdf. Access: May 22, 2019.

Tabari, H.; Talaee, P.H. Multilayer perceptron for reference evapotranspiration estimation in a semiarid region. Neural Computing and Applications, v. 23, n. 2, p. 341-348, 2013.

Yassin, M.A.; Alazba, A.A.; Mattar, M.A. Artificial neural networks versus gene expression programming for estimating reference evapotranspiration in arid climate. Agricultural Water Management, v. 163, p. 110-124, 2016.

License information: This is an open-access article distributed under the terms of the Creative Commons Attribution License (type CC-BY), which permits unrestricted use, distribution and reproduction in any medium, provided the original article is properly cited. 